\title{
Amphibians and reptiles in the new edition of the Animals' Red Data Book of Armenia
}

\author{
Aram Aghasyan ${ }^{1}$, Levon Aghasyan ${ }^{1}$, Eduard Yeghiasaryan ${ }^{2}$, Silva Amiryan ${ }^{2, *}$ \\ ${ }^{1}$ Institute of Zoology of National Academy of Sciences of Armenia, Yerevan, Armenia \\ ${ }^{2}$ Yerevan State University, Yerevan, Armenia
}

Email address:

samiryan@fulbrightmail.org (S. Amiryan)

\section{To cite this article:}

Aram Aghasyan, Levon Aghasyan, Eduard Yeghiasaryan, Silva Amiryan. Amphibians and Reptiles in the New Edition of the Animals' Red Data Book of Armenia, Agriculture, Forestry and Fisheries. Vol. 2, No. 2, 2013, pp. 77-88. doi: 10.11648/j.aff.20130202.14

\begin{abstract}
Being a mountainous country with distinct altitudinal zonality, Armenia retains high diversity and endemism of plant and animal species. New edition of the Red Data Book represents an important official document and a guide towards the efficient conservation of Armenia's unique fauna which demands for the large-scale work on the improvement of legislative background, implementation of population monitoring, early detection of imminent threats, and development of the regional strategy of genetic resources conservation. The goal of this article is to present Amphibians and Reptiles included in the new edition of Red Data Book of Armenia.
\end{abstract}

Keywords: Red Data Book, Biodiversity, Animals, Amphibians, Reptiles, Rare Species, Endangered Species

\section{Introduction}

Encompassing unique fauna, Armenia represents one of the most interesting areas of the Caucasus. Being a mountainous country with distinct altitudinal zonality, Armenia retains high diversity and endemism of animal species [13]. Armenia is among the important centers of origin of some economically valuable plants and animals. Meantime, ever increasing human pressures on ecosystems and landscapes and the overuse of biological resources have caused a substantial change and even degradation of wildlife habitats, bringing a number of species to the brink of extinction. Many species of the national fauna live in the marginal areas of their global ranges or form isolated populations what further necessitates the importance of their research and conservation [1-3].

The strong altitudinal zonality of Armenia's landscapes has left its print also on distribution and specific diversity of vertebrates. Many of 53 reptilian species occurring in the country represent the vanishing endemics of the Armenian Highland and the Caucasus. These species include the northern banded newt, steppe runner; parthenogenetic lizards spread in the country's north, Transcaucasian rat snake, black-headed rhynchocalamus, and Darevsky's viper.

\section{New Edition of the Animals' Red Da-}

\section{ta Book of Armenia}

According to the article 14 of the national law "On fauna", the Red Data Book of the Republic of Armenia is an internationally compliant document compiling information about the status, distribution, ecology, biology, current status and conservation of rare and endangered species.

Preparation of new updated Red Data Book [4, 5] has encompassed the up-to-date information and new field surveys carried out in 2007-2009 by the specialists of the Scientific Centre of Zoology and Hydro ecology, Yerevan State University and other scientific bodies. The status assessment of all species and the assignment of status categories were done in full compliance with the internationally recognized criteria developed by the International Union for Conservation of Nature (IUCN, 2007-2009, ver. 3.1) [6, 7]. The process of evaluation also included the analysis of new knowledge that stockpiled during the 20 years that elapsed after the last Red Data Book.

The following status categories are assigned to the species listed in this Red Data Book:

Extinct species (EX). The taxon is considered extinct if there is no doubt that its last individual has disappeared. The taxon is assessed as extinct if continuous research within the known and/or tentative habitats throughout all historical range in different time frames (seasonal, annual, daily) did not record a single individual. 
Regionally extinct species (RE). The taxon is considered regionally extinct if there is no doubt that its last individual in the region has disappeared. If the taxon used to regularly penetrate into the region in the past, it has also been reckoned regionally extinct provided the last individual has vanished from the region's wild.

Critically endangered species (CR). The taxon is critically endangered if, at the highest probability, it fits any of the criteria (A-E) applicable to the category "Critically Endangered" and faces the highest imminent risk of extinction in the wild. 4. Endangered species (EN). The species is endangered if, at the highest probability, it fits any of the criteria (A-E) applicable to the category "Endangered" and faces a very high risk of extinction in the wild.

Vulnerable (VU). The species is vulnerable if, at the highest probability, it fits any of the criteria (A-E) applicable to the category "Vulnerable" and faces a high risk of extinction in the wild.

Data Deficient (DD). The taxon belongs to the category Data Deficient if available information on its population size and/or distribution is not sufficient to assess, directly or indirectly, the status of this taxon. The taxon of this category can be well-studied and its biology can be wellknown, but information about its abundance and/or distribution does not suffice to judge about its status. The category "Data Deficient" does not represent the threat category. Assignment of this category to a taxon urges for more intense research and admits that further investigations may entitle this taxon to hold any other status category listed above. Reconsideration of the status of the species listed in the previous Red Data Book takes into account their distribution in Armenia (with a database created for each species) and in the world, taxonomic changes, levels of real risk of extinction, and others.

The book covers 153 species of vertebrates, including 7 species of bony fishes (Osteichthyes), 2 species of amphibians (Amphibia), 19 species of reptiles (Reptilia), 96 species of birds (Aves) and 29 species of mammals (Mammalia).

Each species name is provided in Latin, Armenian, Russian and English. Its species account comprises the status, brief description of the assessment, brief description of the species, distribution (including the areas of occurrence), ecological and biological traits, major threats, and actual and proposed conservation measures. Contemporary advancements in taxonomy are taken into account. Each species account contains an adult's image and a distribution map (dots or polygon) [4].

New edition of the Red Data Book represents an important official document and a guide towards the efficient conservation of Armenia's unique fauna which demands for the large-scale work on the improvement of legislative background, implementation of population monitoring, early detection of imminent threats, and development of the regional strategy of genetic resources conservation.

The Amphibians and Reptiles included in the new edition of Red Data Book of Armenia are represented below.

\section{Northern Banded Newt, Ommatotri- ton Ophryticus (Berthold,1846) [2, 8- 10]}

\author{
Class AMPHIBIA
}

Order CAUDATA

Family Salamandrids, Salamandridae

Status. Local relic populations in the North of Armenia. The species is registered in the Red Books of former USSR, Russia and Georgia as well in the Annex 2 of Bern Convention. According to the International Union for Conservation of Nature and Natural Resources (IUCN) Red List Criteria it is evaluated as Critically Endangered - CR B2ab (iii,v):

Distribution. Israel, Lebanon, Syria, Asia Minor, West Caucasus.

Distribution in Armenia. It is found in 3 small ponds with a total area of 400-600 square meters which are situated at the lower edge of mixed forest at an altitude of $1000 \mathrm{~ms}$ above sea level in the surroundings of the villages Akhtala, Odzun and Dsegh.

Habitats. They are mostly met in coniferous, broadleaved and mixed forests, mountain slopes where they form peripheral populations of geographic isolate. They generally inhabit various stagnant and slow-flowing basins (lakes, artificial ponds, canals, swamps etc.) where there is a shelter and aquatic vegetation that serve as egg-laying site. The total are of these basins varies from 1 to 500 square kilometers, the depth- 0,1-3 m.

Biological peculiarities. They pass summer and winter in the land finding their hiding places under the bark of rotten trunks, stones and in the cracks of the rocks. In spring and at the beginning of summer they remain in the clear, stagnant and flowing forest basins that are rich in aquatic vegetation. They feed on minor crustaceans, mollusks, insects and worms. They breed from April to May, lay eggs at a depth of $50 \mathrm{~cm}$ in separate sections, 1-53 eggs per day, interval of 2 to 11 days. They reach puberty at the age of 35. Duration of life is $8-21$ years in different parts of the distribution area of the subspecies.

Quantity and its change tendencies. The quantity makes up 1500-1800 individuals in the wild.

Main factors of endangering. Degradation of the forests, destruction of small basins, overgrazing by cattle, industrial pollution, use of poisonous chemicals have negative impact on the quantity of Ommatotriton ophryticus. The illegal mass catch of tritons that are sold to the amateurs of the terrariums, presents serious danger to the population.

Conservation measures. Laboratorial methods of reproduction and breeding of the species are worked out. 70 laboratory- raised individuals were released (set free) in Lake Parz-lich of Dilijan. It is necessary to grant the status of specially protected natural area (SPA) i.e. sanctuary to the habitats.

\section{Eastern Spadefoot, Pelobates Syria-}




\section{cus Boettger, 1889 [2, 8, 11-14]}

Class AMPHIBIA

Order ANURA

Family Spadefoot toads, Pelobatidae

Status. Rare, decreasing in quantity species with narrow area of distribution. It is registered in the Red Books of former USSR and Azerbaijan. It is protected by the Bern Convention in Europe. The species is included in IUCN Red List (ver. 3.1) as LEAST CONCERN-LC. According to the IUCN (International Union for Conservation of Nature and Natural Resources) Red List Criteria it is evaluated as VULNERABLE- VU B2ab (ii, iii).

Distribution. Syria, Palestine, Israel, Asia Minor, the Balkan Peninsula, the Caucasus.

Distribution in Armenia. It is distributed in south-eastern regions. Very rarely it is met in the central and southern regions of the republic: villages Jrvejh, Arinj, Voghjaberd (Kotayq Marz), Rind (Vayots Dzor Marz), in the surroundings of Sisian (Syuniq Marz).

Habitats. It can be met in forested areas, in steppe and semi-desert foothills and in mountain lowlands, in relatively open landscapes.

Biological peculiarities. It leads exclusively digging, night life-style. Reproduction takes place from the end of March till the middle of May in undrained, rich in vegetation lakes, man-made lakes and in cane swamps. Adult individuals stay in the lake to lay eggs, after they come to the surface. The female lays eggs on the leaves of submerged plants, in case of their absence on the bottom of the basin.

Quantity and its change tendencies. According to the calculation of 1956 5-6 individuals were marked on the waterside of the basin of Vayots Dzor Marz (on $1 \mathrm{~km}$ ). Nowadays the quantity has severely decreased, in some places it extinct.

Main factors of endangering. Draining and pollution of basins (reservoirs), development of lands for agricultural activity and destruction of natural habitats.

Conservation measures. Distribution areas of the species are not conserved. 1985-1986 1500 laboratory-raised individuals were released in Azat Reservoir (Ararat Marz), where population is in favorable conditions. It is necessary to grant the status of specially protected natural area (SPA) i.e. sanctuary to the habitats.

\section{Spur-Thighed Tortoise, Testudo Graeca (Linnaeus, 1758) [15]}

Class REPTILIA

Order TESTUDINES

Family Tortoises, Testudinidae

Status. The species is included in IUCN Red List (ver. 2.3) as Vulnerable- VU A1cd. It is registered in the list of Convention on International Trade in Endangered Species of Wild Fauna and Flora (CITES), as well as in the Annex
2 of Bern Convention. It is registered in the Red Book of former USSR. According to the IUCN (International Union for Conservation of Nature and Natural Resources) Red List Criteria it is evaluated as Vulnerable - VU A2cd; $\mathrm{B} 1 \mathrm{a}+2 \mathrm{ab}$ (iii).

Distribution. North Africa (from Morocco to Lebanon), South Europe (Italy, South Spain, the Balkans), Southwestern Asia (Turkey, Iran, Syria, Lebanon, Jordan, Israel), islands of Majorca, Cyprus, Sardinia, Sicily, the Canaries. In North Eurasia it is met in the coasts of the Black Sea, from Anapa to Sukhumi, as well as in East Georgia, Azerbaijan, and Dagestan.

Distribution in Armenia. T.g.ibera subspecies is distributed in the northeastern region of the republic, (Araks River valley), T.g.armeniaca subspecies is spread in the southern region. Area of distribution of T.g.armeniaca is divided into several populations which are situated in Ararat Plain and in the southernmost part of Armenia: Meghri region.

Habitats. It inhabits various habitats: dry steppes, slopes with meager grass cover, shrubs, open forest or mountain forests, as well as low-altitude forests and gardens.

Biological peculiarities. They are active from April till mid-November. They usually winter in the nests of foxes and badgers. They feed on juicy herbs and invertebrates in small quantity. Coupling takes place from April to May. They lay eggs 3 times per one season beginning from June, hiding their eggs in the hole dug in the ground (2-8 eggs). Development period lasts 2-3 months. They reach puberty at the age 12-14.

Quantity and its change tendencies. The approximate number makes up 900-1000 individuals in Armenia. 1-5 individuals are met on 10 ha.

Main factors of endangering. Mainly development of distinctive habitats (especially in the south of Armenia) and illegal, uncontrolled catching by the poachers.

Conservation measures. It is conserved in Shikahogh and Khosrov State Reserves, as well as in some state sanctuaries (Bokhaqar, Goravan Sands, Ijevan etc.). It is conserved in numerous zoological gardens of the world and among terrariumists. It was successfully bred in the Zoological Institute of NAS of RA. Necessary: To take under control main habitats that are outside specially protected areas. To forbid turtle catch. To undertake reproduction of the turtles for the restoration of exhausted populations.

\section{Horvath's Toadhead Agama, Phryno- cephalus Horvathi (Mehely, 1894) [16]}

Class REPTILIA

Super order SQUAMATA

Order SAURIA

Family Agamas, Agamidae

Status. Previously it was regarded as subspecies of $P$. helioscopus. Species on the verge of extinction and severely few in number. The species is included in IUCN Red List 
(ver. 2.3) as Critically Endangered A2c. According to the IUCN (International Union for Conservation of Nature and Natural Resources) Red List Criteria it is evaluated as Critically Endangered-CR B2 ab (I, ii, iii).

Distribution. Northwestern and western parts of the Central Plateau of Iran, Azerbaijan, Northeastern Turkey up to East Transcaucasia.

Distribution in Armenia. Single populations are known in the Araks River valley. It is conserved in Baghramyan, Armavir, Ejmiadzin regions of Ararat Marz and in separate parts of Artashat and Ararat Marzes.

Habitats. They inhabit sandy and saline semi deserts with xerophilous light vegetation, sometimes with the presence of achillea, saline, partly wormwood vegetation at an altitude of $800-1050 \mathrm{~m}$ above sea level.

Biological peculiarities. They come out of hibernation at the beginning of March and activity continues up to November. They feed on arthropods (ants, minor beetles, wood louse, larvae of flies, spider etc.). They lay eggs 2-3 times per one year. 2-7 egg mass. Duration of life is up to 3 years.

Quantity and its change tendencies. According to literature data it was distributed in semi deserts and relic islands of semi desert sands. All these landscapes are subjected to anthropogenic influence which increases year by year. As a result the quantity of natural habitats of Phrynocephalus horvathi reduces everywhere. Today only 6 individuals are known conserved in the Araks River valley where the quantity is very small. The density forms 1-2 individuals in Goravan Sands State Sanctuary, 2-3 individuals in the surroundings of Boghakar, 1-2-in the surroundings of Armavir town, 2-3 individuals in the surroundings of Bagharan on 1 hectare. It makes up 1.5-2 in the sands of Ararat region, 2-3 individuals in Armavir region on 1 ha.

Main factors of endangering. Extensive development of semi deserts of the Ararat Plain for sowing cultivated plants, irrigation of soils, extension of villages, establishment of roads and artificial basins led to the degradation and extinction of the most parts of the known populations of the species. Overgrazing and illegal, uncontrolled poaching are among the threats.

Conservation measures. It is conserved in Goravan Sands and Vordan Karmir State Sanctuaries. Breeding is possible in terrarium in case of providing certain conditions. It is necessary to fence the territory of sanctuaries to prevent grazing and to carry out measures for the restoration of exhausted populations.

\section{Chernov's Snake-Eyed Skink, Able- pharus Chernovi Darevsky, 1953 [11, 17, 18]}

\section{Order SAURIA}

Family Skinks, Scincidae

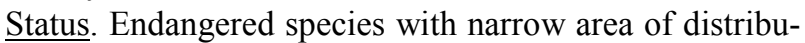
tion and very small quantity. The species is included in
IUCN Red List (ver. 3.1) as Least Concern - LC. According to the IUCN (International Union for Conservation of Nature and Natural Resources) Red List Criteria it is evaluated as Critically Endangered- CR A2ac; B2ab (ii,iii).

Distribution. It is met only in central Armenia, Turkey (southern and central parts of Anatolia) and North Syria in the territory of North Eurasia.

Distribution in Armenia. It inhabits only the mid-stream of Hrazdan River valley. Fragmented populations are known in the surroundings of the villages Karashamb, Teghenik and Bjni. The overall extent of occurrence of the populations covers 3-4 square kilometers.

Habitats populations. It inhabits mountain xerophyte steppes of declining slopes covered with various cereals and grass. It is also met in the cracks of mountain rocks devoid of vegetation. It is generally met between small stones under which it passes most of the time.

Biological peculiarities. They come out of hibernation in the end of March. They hide in deep shelters in hot, dry months and come out on the surface of the land in September. They feed on small hymenoptera, ants, dipters (dipterous insects) beetles and spiders.

Quantity and its change tendencies. The overall quantity is 250-300 individuals. It is possible to find 1-2 lizards by turning over the stones (on 1ha) in spring (1985 data). Extent of occurrence of the species was intensively affected by anthropogenic factors in the latest years and the searches of recent years were unsuccessful in this region .Nowadays some parts of the extent of occurrence of the species are fully destructed and developed.

Main factors of endangering. Development of habitats and constructional works for the expansion of villages Karashamb, Arzakan, Teghenik, and Bjni. Use of mountain steppes for agricultural purposes in the surroundings of these villages also has considerable impact which led to the overall change of the cenosis.

Conservation measures. Area of occupancy is not conserved. It is necessary to take under control habitats and to grant them status of specially protected areas (SPA) i.e. sanctuaries.

\section{Golden Grass Mabuya, Trachylepis Septemtaeniata Reuss, 1834 [11,17,18]}

\author{
Order SAURIA
}

Family Skinks, Scincidae

Status. The species is included in IUCN Red List (ver. 3.1) as Data Deficient -DD. According to the IUCN (International Union for Conservation of Nature and Natural Resources) Red List Criteria it is evaluated as VulnerableVU B1ab(iii)+2ab(iii).

Distribution. It is distributed in the northwestern region of Saudi Arabia, South Iran, Iraq, Bahrain, North Iran, Eritrea, Turkmenistan, Transcaucasia. Northern border of the area of distribution passes through the south of Armenia, Azerbaijan and Turkmenia. 
Distribution in Armenia. They are known from the cities Yerevan, Yeghegnadzor Ararat and Meghri, in the surroundings of the villages Areni, Agarak, Lehvaz, Vedi, Astazur, Arsni, Jrvejh, as well as Urts mountain chain.

Habitats. It inhabits more or less inclined slopes of the mountains and foothills covered with scarce (sparse), xerophilous (xerocolous) vegetation. The species can also be met on the rocks of stony slopes of gorges, heaps of large stones and cracks. They are met partly in the gardens, in abandoned and tumbledown buildings, as well as biotopes of dry or mid-moisture, rocky, rich in hiding places at an altitude of 500-1400 $\mathrm{m}$ above sea level. Cracks in the rocks, empty parts under the stones, seldom nests of rodents serve as hiding places for them.

Biological peculiarities. They come out of hibernation at the end of March. They feed on various invertebrates. Coupling is observed at the beginning/half of May. The female gives birth to 3-8 young at the beginning of July.

Quantity and its change tendencies. The quantity and density of the populations are unequal and are subjected to significant variations year by year. The populations in south are more numerous (surroundings of Meghri and villages Agarak, Nyuvadi). Quantity is stable here and is less subjected to variations as a result of mild winter. Less than 8 individuals of different age in dry biotopes on 1 ha. The quantity of Trachylepis septemtaeniata Reuss is severely decreased in most parts of Armenia, in some places lizard has become very rare, whereas the species is practically extinct in Ararat Plain.

Main factors of endangering. Development of habitats for agricultural purposes, alteration of landscapes, overgrazing, current regime shift of the springs in foothill belts which leads to the change of natural biotopes. Illegal catch.

Conservation measures. It is conserved in Khosrov Forest State Reserve, Goravan Sands State Sanctuary and Arevik National Park. To strengthen control over illegal catch.

\section{Schneider's Skink, Eumeces Schnei- deri (Daudin, 1802) [11, 17, 18]}

Order SAURIA

Family Skinks, Scincidae

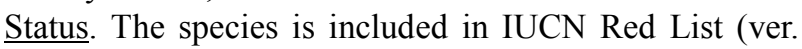
3.1) as Least Concern. According to the IUCN (International Union for Conservation of Nature and Natural Resources) Red List Criteria it is evaluated as Vulnerable- VU B1ab(iii)+2ab(iii).

Distribution. The species is widely distributed from North Africa and Asian Near East up to Northwestern Iran. The northern boundary of the distribution area passes through South Dagestan, Georgia, Armenia, South Uzbekistan, Tajikistan and Turkmenia. In the south it reaches Pakistan and Syria.

Distribution in Armenia. It is known from Ararat Plain, Arpa River gorge, Araks River valley and southern foothill regions of the republic.
Habitats. It inhabits very rocky semi deserts covered with xerophilous (xerocolous) vegetation at an altitude of 400-1500 m above sea level. It can be met in the parts of fixed sands in the surroundings of the village Goravan, it is partly met in riverside brush woods. It inhabits various rock formations in dry steppe belt, more often it can be found in plain areas near the colonies of Meriones and other rodents. Often inhabits gardens and neighboring areas: on stone fences, in empty and semi-collapsed buildings, cattle sheds. Holes in the rocks, cavities under stones, deep cracks of the soil, of rodents serve as hiding places for them. It can sometimes dig private nests of $150 \mathrm{~cm}$ long and $60 \mathrm{~cm}$ deep in smooth soil the entrance of which is settled at the base of shrubs and large stones.

Biological peculiarities. They are mostly active in the afternoon in spring, in the morning or evening in summer. They do not at all come out on the surface of the soil at the end of summer; it is supposed that they fall into hibernation. They feed on various invertebrates, mostly insects, as well as plants, berries, fruits, seeds. Skink lays eggs in the end of July/beginning of August. 6-9 eggs in the egg mass.

Quantity and its change tendencies. Despite wide distribution the quantity is rather small in most parts of the area of distribution in Armenia. 3 lizards were calculated in Hrazdan River gorge on the area of 175 x $150 \mathrm{~m}$ in May. Populations of the village Metsamor, Kosh, Jrvej, Verin Dvin, Narek and Urtsadzor have the same density. The populations are in more favorable conditions in the south of the republic in foothill belt. 12 individuals of different age were calculated in on 1 ha in Meghri region in the end of July.

Main factors of endangering. Development of habitats for agricultural purposes, alteration of landscapes, illegal catch.

Conservation measures. It is conserved in Khosrov Forest State Reserve, Goravan Sands State Sanctuary and Arevik National Park. It is necessary to strengthen control over illegal catch.

\section{Steppe Runner, Eremias Arguta Transcaucasica Darevsky, 1953 [2, 11, 17, 18]}

Order SAURIA

Family Lacertids, Lacertidae

Status. Very few in number, endangered subspecies fragmented from the main area of distribution that is met only in Armenia. The species is included in IUCN Red List (ver. 3.1) as Critically Endangered A2c. According to the IUCN (International Union for Conservation of Nature and Natural Resources) Red List Criteria it is evaluated as Critically Endangered - CR A2c; B2ab (ii, iii).

Distribution. This species is widely distributed from the Northeastern Romania in the west up to the Southwestern Mongolia and Northwestern China, as well as up to Turkey and south of Iran. It is met in Moldova, Ukraine, European 
part of Russia, in Kazakhstan, countries of Asia Minor, in the South Caucasus and Transcaucasia within the borders of North Eurasia.

Distribution in Armenia. The only known population is situated in the south shore of Lake Sevan in the surroundings of the village Noraduz.

Habitats. It inhabits sands of Noraduz. It is met both in mellow and firm soil areas inhabiting mountain-xerophyte steppes of Lake Sevan basin.

Biological peculiarities. The female lays 1-12 eggs.

Quantity and its change tendencies. 1961 the last 27 lizards conserved in the surroundings of Martuni were caught in narrow strip of land, between the fields and the lake-shore of the Sevan and were let free in the neighborhood of the village Noraduz. These individuals gave birth to new population which gradually enlarges its borders. Nowadays their quantity makes up 80-150 individuals.

Main factors of endangering. Overgrazing, cultivation of the habitats of this specie for agricultural purposes.

Conservation measures. It is conserved in Sevan National Park. It is necessary to fence uncultivated area in the surroundings of the village Noraduz and strengthen conservation of the subspecies.

\section{Transcaucasian Racerunner, Ere- mias Pleskei Bedriaga, 1907 [2, 11, 17, 18]}

\section{Order SAURIA}

Family Lacertids, Lacertidae

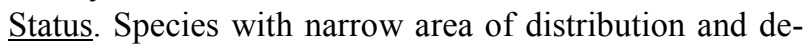
creasing quantity. The species is included in IUCN Red List (ver. 3.1) as Critically Endangered A2c. According to the IUCN (International Union for Conservation of Nature and Natural Resources) Red List Criteria it is evaluated as Critically Endangered - CR B2ab (ii, iii).

Distribution. East Turkey, Northwestern Iran and East Transcaucasia.

Distribution in Armenia. It is met in the left riverside of Araks River valley to the west of Ejmiadzin up to the southern foothills of Meghri mountain chain.

Habitats. It lives in fixed sands with the presence of $\mathrm{Cal}$ ligonum, wormwood, astragalus and rarely with the presence of cereals. Sometimes it can be met in rocky wormwood and saline semi-deserts. Short nests $(10-15 \mathrm{~cm})$ situated at the base of the bushes serve as shelters.

Biological peculiarities. It winters from SeptemberOctober up to the first half of April. It feeds on ants, small beetles, hymenoptera, dipters (dipterous insects) larvae and spiders. Coupling takes place from April up to first half of June. Egg laying (3-4 eggs) takes place from June till the beginning of August. The young of the first year can be met from mid-July till the end of September.

Quantity and its change tendencies. The quantity has severely decreased in the last 10-15 years: several populations of Araks River valley has were exterminated. It is completely extinct in most parts of the Ararat Plain.

Main factors of endangering. Development of habitats for agricultural purposes, overgrazing and alteration of landscapes.

Conservation measures. It is conserved in Khosrov Forest State Reserve, Goravan Sands State Sanctuary and Arevik National Park. It is necessary to fence Goravan Sands State Sanctuary.

\section{Lizard of Asia Minor, Parvilacerta Parva Boulenger, 1887 [2, 11, 17, 18]}

\section{Order SAURIA}

Family Lacertids, Lacertidae

$\underline{\text { Status. }}$ Very few in number species that is on verge of extinction. It is registered in the Red Book of former USSR. It is protected by Bern Convention. The species is included in IUCN Red List (ver. 3.1) as Least Concern. According to the IUCN (International Union for Conservation of Nature and Natural Resources) Red List Criteria it is evaluated as Critically Endangered - CR A2ac.

Distribution. It is widely distributed in Asia Minor.

Distribution in Armenia. It is found in Central and North Armenia, only in the uncultivated and impassable parts of Spitak region and in the surroundings of the village Lanjik in Shirak Marz. It is also found in the northern shores of Tavush Reservoir.

Habitats. It inhabits rocky, mountain-xerophilous steppes, sometimes rises on the skeleton slopes of the mountains covered with scarce, xerophilous vegetation.

Biological peculiarities. It lays eggs twice per year from the end of June to the beginning of July and from the end of July to the beginning of August. It lays 2-5 eggs. The young hatch out from the end of July/September.

Quantity and its change tendencies. Calculations made in 1982 had shown that 2-5 individuals were met on 1 ha. At present the quantity has sharply decreased.

Main factors of endangering. The main reasons of the destruction of biotopes are economic development of natural habitats and the abolition of the populations caused by grazing and mowing.

Conservation measures. The area of the population is not conserved. It is necessary to take under conservation mountain-xerophilous steppes of Spitak region and Aragatsotni Marz and to establish small sanctuaries in those areas.

\section{Meadow Lizard, Darevskia Praticola (Eversmann, 1834) [2, 19]}

\section{Order SAURIA}

Family Lacertids, Lacertidae

Status. The species is included in IUCN Red List (ver. 3.1) as Near Threatened. According to the IUCN (International Union for Conservation of Nature and Natural Resources) Red List Criteria it is evaluated as Vulnerable VU B1ab(iii)+2a. 
Distribution. North-west of the Balkan Peninsula, Caucasus, North-west of Iran.

Distribution in Armenia. Isolated populations live in the north of Armenia.

Habitats. It is met mainly in foothill, valley, mountainous, generally deciduous forests where it stays in the margin of the forest, glades, roadsides and shrubs.

Biological peculiarities. It feeds on insects: small beetles, ants, orthopterous, larvae, spiders, worms, wood louse. It comes out hibernation in the end of April. Coupling takes place in the end of May. It lays eggs (2-6 eggs) from the middle of June to mid-July. The young hatch out in AugustSeptember.

Quantity and its change tendencies. Not known.

Main factors of endangering. Degradation of biotopes and ecosystems as a result of illegal felling.

Conservation measures. It is conserved in Dilijan National park. It is necessary to carry out calculation of the quantity and observations on the assessment of the population.

\section{Dahl's Lizard, Darevskia Dahli (Da- revsky, 1957) $[2,19]$}

\section{Order SAURIA}

Family Lacertids, Lacertidae

Status. The species is included in IUCN Red List (ver. 3.1) as Near Threatened. According to IUCN (International Union for Conservation of Nature and Natural Resources) Red List Criteria it is evaluated as Endangered - EN $\mathrm{B} 1 \mathrm{a}+2 \mathrm{a}$.

Distribution. It is distributed in the borders of North Armenia and South Georgia up to the north of the foothill Kura River valley.

Distribution in Armenia. Modern area of distribution is fragmented into several isolated populations which are situated in the North of Armenia.

Habitats. It is met on temperate dry slopes of the gorges, on the rocks at an altitude of 900-1700 m above sea level, in the forest belt. Partly it can be met in the rocky sites of the mountain steppes staying in the forest margin, roadside and in the shrubs. It often inhabits forest ruins, the fences made of stones and walls of the buildings.

Biological peculiarities. It comes out hibernation from the beginning to mid-April. It feeds on insects, their larvae, spiders wood louse and earthworm. Reproduction takes place parthenogenetically (virgin birth).It lays 2-5 eggs at the beginning of June till mid-July. The baby animals hatch out from mid-August till the end of September.

Quantity and its change tendencies. The area of distribution is fragmented into several small, separated from each other parts, where quantity changes are not known.

Main factors of endangering. Reconstruction of the roads, changes of microclimate as a result of decrease of river current.

Conservation measures. It is conserved in Dilijan Na- tional Park.

It is necessary to carry out calculation of the quantity and observations on the assessment of the population.

\section{Rostombekov's Lizard, Darevskia Rostombekovi Darevsky 1957 [2, 19]}

\section{Order SAURIA}

Family Lacertids, Lacertidae

Status. The species is included in IUCN Red List (ver. 3.1) as Endangered B1ab (i,iii). According to IUCN (International Union for Conservation of Nature and Natural Resources) Red List Criteria it is evaluated as Endangered - EN B2ab (ii, iii).

Distribution. Comparatively restricted area of distribution in North Armenia and in the adjacent regions of Azerbaijan. The main distribution area occupies the middle riverside part of Kura River valley and the gorge of the right streams in the borders of Georgia, North Armenia and Northwestern Azerbaijan.

Distribution in Armenia. The distribution area of the species is bordered by the forest regions of the Ararat Plateau in the borders of North Armenia in the territory of the republic. The southern border of the distribution area passes through Aghstev and Pambak River gorges, longwise Bazum mountain chain to the West of Spitak City. The northern border of the distribution area passes through northeastern part of Papakar mountain range where northernmost places of discovery of the species are known Noyemberyan and Sevkar regions. Besides, one isolated population is known in the southeastern shore of Lake Sevan: surroundings of the village Tsovak.

Habitats. They are distributed mainly in the forest belts, in some places they pass to mountain steppe belt at an altitude of $800-1600 \mathrm{~m}$ above sea level. Only the population found in Lake Sevan shore lives at an altitude of $2000 \mathrm{~m}$ above sea level.

Biological peculiarities. It comes out hibernation from in the end of March/beginning of April. It feeds on insects and other small invertebrates. Reproduction takes place parthenogenetically (virgin birth). Egg laying- at the end of June/beginning of July. 2-4 eggs in the egg mass. The baby animals hatch out at the end of August/beginning of September.

Quantity and its change tendencies. 50-60 individuals are met on tha in distinctive biotopes.

Main factors of endangering. Economic activity in mountain-steppe belts and degradation of distinctive habitats.

Nowadays the population situated in Lake Sevan shore has become extinct because here we have its sympatric species: D. unisexualis being better adapted to high mountain conditions forces out $D$. rostombekovi.

Conservation measures. It is conserved in Sevan and Dilijan National parks. 


\section{White-Bellied Lizard, Darevskia Un- isexualis (Darevsky, 1966) [2, 19]}

\section{Order SAURIA}

Family Lacertids, Lacertidae

Status. The species is included in IUCN Red List (ver. 3.1) as Near Threatened. According to IUCN (International Union for Conservation of Nature and Natural Resources) Red List Criteria it is evaluated as Vulnerable - VU B1a.

Distribution. Area of distribution of the species is fragmented into several isolated populations in the borders of the North and Central Mountainous Armenia and in the neighbouring regions of East Turkey and South Georgia.

Distribution in Armenia. Northern and central mountain regions of Armenia.

Habitats. It inhabits rocks of the mountain-steppe belt, heaps of stones and stony slopes at an altitude 1700-2000 $\mathrm{m}$ above sea level.

Biological peculiarities. It comes out of hibernation from mid-April/beginning of May. It feeds generally on beetles and hymenoptera. Reproduction takes place parthenogenetically (virgin birth). Egg laying takes place at the end of June-at the beginning of July. 2-7 eggs in the egg mass. The baby animals hatch at the end of August/beginning of September.

Quantity and its change tendencies. The quantity of the species is stable.

Main factors of endangering. Reduction of suitable habitats as a result of agricultural activity.

Conservation measures. It is conserved in Sevan National park.

\section{Transcaucasian Rat Snake, Zamenis Hohenackeri (Strauch, 1873) [1, 3, 5, 20]}

\section{Order SERPENTES}

Family Colubrids, Colubridae

Status. It is registered in the Red Book of former USSR. According to IUCN (International Union for Conservation of Nature and Natural Resources) Red List Criteria it is evaluated as Vulnerable - VU B1ab (iii).

Distribution. Asia Minor, Northeastern Iran, South Lebanon, North Israel, North Ossetia, Chechnya, Ingushetia, Daghestan, Azerbaijan, Georgia, Armenia.

Distribution in Armenia. Southern and northern parts of the republic, but it is mostly met in the foothill regions of Araks River valley.

Habitats. It is met on the rocky slopes covered with xerophilous shrub sand herbs, on the rocks and in collapsed the stones in mountain-steppe belt. It lives between rocks, juniper light forests in Khosrov Forest State Reserve. It is met in oak light forest, in the shrubs, on the rocky riversides and on the slopes gorges in Hamberd river gorge. In the surroundings of Yerevan city it inhabits open and rocky parts of the slopes in fruitful gardens and vineyards, be- tween ruins and fences. It mounts up to $2200 \mathrm{~m}$ above sea level.

Biological peculiarities. It comes out hibernation at the beginning of April or in the middle of it. It feeds on mouselike rodents, lizards. Young individuals feed on insects. Egg laying- in the middle of June. 3-7 eggs in the egg mass. Baby snakes hatch out at the beginning of September.

Quantity and its change tendencies. 1-2 individuals are met in Khosrov Forest State Reserve during 5 hours walk $(6-7 \mathrm{~km})$ in spring. As a result of illegal catch and destruction of distinctive habitats the quantity has sharply decreased in the surroundings of Yerevan city.

Main factors of endangering. Poaching, destruction of distinctive habitats.

Conservation measures. It is conserved in Khosrov Forest and Shikahogh State Reserves Arevik National Park. It is registered in the Red Books of the former USSR, Georgia and Azerbaijan. It is necessary to carry out strong control over the catch of this species.

\section{Dark-Headed Dwarf Racer, Pseudo- cyclophis Persicus (Anderson, 1872) $[1,20,21]$}

\section{Order SERPENTES}

Family Colubrids, Colubridae

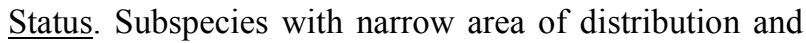
few in quantity. According to IUCN (International Union for Conservation of Nature and Natural Resources) Red List Criteria it is evaluated as Critically endangered - CR B2ab (i, ii, iii).

Distribution. Southeastern Turkey, North and West Iraq, Afghanistan, Palestine and North-West India to the east : Sind and Punjab. North-eastern border of the distribution area passes through the southern part of Turkmenistan, from western Koppet Dag to the east through the central part to Seraskh where comparatively few in number examples were found.

Distribution in Armenia. The only example of Pseudocyclophis $p$. persicus subspecies was found $5 \mathrm{~km}$ to the west from the village Agarak in Meghri region.

Habitats. The individual of the Agarak was discovered in the western rocky slope of the gorge, with secondary forest formations in semi-desert belt, near a bush $\left(28-30^{\circ} \mathrm{C}\right.$ temperature).

Biological peculiarities. It has hiding behavior.

Quantity and its change tendencies. Only one individual has been discovered since now (male). It is very rarely met in the wild.

Main factors of endangering. Development of distinctive habitats.

Conservation measures. It is conserved in Arevik National Park. It is necessary to specify and draw a map of the habitats and to include them in the reserve belt of Arevik National Park. 


\section{Black-Headed Rhynchocalamus, Rhynchocalamus Melanocephalus Sa- tunini (Nikolsky, 1899) [1, 20, 22]}

Order SERPENTES

Family Colubrids, Colubridae

Status. The most rareest and less observed species of Transcaucasiad.Very few individuals are known. It is registered in the Red Book of former USSR. According to IUCN (International Union for Conservation of Nature and Natural Resources) Red List Criteria it is evaluated as Vulnerable - VU B2ab (i, iii).

Distribution. Asian Near East up to the western part of Iran in the west, Armenia and Nakhichevan.

Distribution in Armenia. It is distributed only in Araks River valley where it mounts foothills up to $1200 \mathrm{~m}$ above sea level.

Habitats. It is met only in wormwood semi-deserts, on dry and very rocky slopes where there are bare rocks and numerous boulders with xerophyte vegetation, as well as in phrygana.

Biological peculiarities. It leads hiding twilight mode of life and almost doesn't appear on the surface of the land during the afternoon. Biology is almost unexamined.

Quantity and its change tendencies. The quantity of this species is probably stable in the wild. 7 individuals were caught in the territory of the former USSR: generally in the surroundings of the cities or in developed lands. Up to the present days 19 individuals have been discovered in Transcaucasia 17 of which in Armenia and in Nakhichevan.

Main factors of endangering. Development of distinctive habitats.

Conservation measures. It is conserved in Khosrov Forest State Reserve and Arevik National Park. It is necessary to take under protection distinctive habitats of Rhynchocalamus melanocephalus satunini adjacent to Khosrov Forest State Reserve uniting these areas to the reserve.

\section{Cat Snake, Telescopus Fallax (Fleschmann, 1831) [1, 20]}

\section{Order SERPENTES}

Family Colubrids, Colubridae

Status. The species is included in IUCN Red List (ver. 3.1) as Least Concern. According to IUCN (International Union for Conservation of Nature and Natural Resources) Red List Criteria it is evaluated as Vulnerable - VU B1ab (iii).

Distribution. North Iran, Iraq, eastern part of Asia Minor, North Syria, Azerbaijan, Dagestan, Georgia, Armenia. The area of distribution of the species also includes the Balkan Peninsula, a number of islands of the Aegean and Mediterranean Seas, Lebanon and Israel.

Distribution in Armenia. In the South it is known from river valleys and foothills of Araks and in the north from that of Kura River.
Habitats. More often it can be met on the rocky slopes of mountains covered with shrubs and grass, on the rocky parts of mountain-xerophyte steppes, in juniper light forest, in cultivated landscapes: fruitful gardens and vineyards. It is also met in the open achillea and wormwood semideserts. It is does not avoid people and it is often met on the roofs of the houses: on the cracks of stone walls and hedges. They use cracks of the rocks, cavities under the stones and the nests of various digging animals as shelter.It is known at an altitude of $2000 \mathrm{~m}$ above sea level.

Biological peculiarities. In spring it comes out at the beginning or in the middle of March. Wintering begins in the end of September/October. It easily climbs the trees and the walls of the buildings. Most of the time it passes under the stones. It feeds mainly on lizards, sometimes on rodents. There is no information about reproduction in Armenia. The female lays 6-9 eggs $(10-13 \times 27-35 \mathrm{~mm})$ in other parts of the distribution area in the end of June/beginning of July. The babies hatch in September.

Quantity and its change tendencies. The quantity is low everywhere. 1-2 individuals can be met in Khosrov State Reserve during afternoon walk in spring.

Main factors of endangering. Poaching, development of distinctive habitats.

Conservation measures. It is conserved in Khosrov Forest State Reserve and Arevik National Park. It is necessary to take under protection isolated populations in the north of Armenia (establishment of sanctuaries), to carry out severe control over the illegal catch of this species.

\section{Darevsky's Viper, Vipera (Pelias) Darevskii Vedmederja, Orlov Et Tu- niyev, 1986 [1, 20, 23-26]}

\section{Order SERPENTES}

Family Vipers and pit vipers, Viperidae

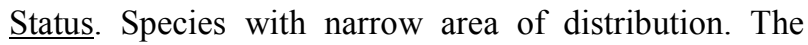
species is included in IUCN Red List (ver. 3.1) as Critically Endangered B1ab (ii,iii) $+2 \mathrm{ab}$ (ii,iii). According to IUCN (International Union for Conservation of Nature and Natural Resources) Red List Criteria it is evaluated as Critically Endangered CR B2ab (ii, iii).

Distribution. The distribution area of the species includes south-western part of Javakhq mountain chain in the boundaries of Armenia up to the border with Georgia (mount Achkasar) at an altitude of $2350-3000 \mathrm{~m}$ above sea level.

Distribution in Armenia. Shirak Marz, Ashotsk region. According to 2008 data extent of occurrence covers no more than 200 ha.

Habitats. The species inhabits rocky mountain slopes and rock protuberances covered with the heaps of flat stones in subalpine belt.

Biological peculiarities. They are active at the beginning of May till the end of September. They feed on lizards and invertebrates. Coupling connubium begins from the begin- 
ning to the middle of May. Live-bearing (viviparous) species. The babies (5-8) are born in mid-September. Shortly after being born ecdysis begins which lasts 1 hour. The late terms of being born in the high altitude belts give reason to suppose that the newly-born babies immediately pass to hibernation and begin to feed in spring of the coming year.

Quantity and its change tendencies. The density of the population in distinctive biotopes is rather high: 10-12 individuals were counted on tha in different years.

Main factors of endangering. Degradation of distinctive habitats, intensive development of high altitude meadows, uncontrollable grazing and illegal catch.

Conservation measures. It is conserved in Lake Arpi National Park. Since 2004 within the frameworks of the program "Measures on the conservation of Vipera (Pelias) darevskii in the Caucasus" conservation measures have been worked out and are implemented for singling out of necessary biotopes and for giving the category of specially protected nature areas to those areas. It is necessary to separate and fence distinctive biotopes of the species and to include them in the reserve zone of Lake Arpi National Park, to carry out severe control over the illegal catch of the species as well.

\section{Armenian Steppe Viper, Vipera (Pe- lias) Eriwanensis (Reuss, 1933) [1, 20]}

Order SERPENTES

Family Vipers and pit vipers, Viperidae

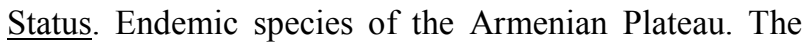
species is included in IUCN Red List (ver. 3.1) as Vulnerable B1ab (iii,v). According to IUCN (International Union for Conservation of Nature and Natural Resources) Red List Criteria it is evaluated as Vulnerable -VU B1ab(iii, v).

Distribution. The area of distribution of the species includes mountainous regions of the East Transcaucasia, as well as neighboring northern regions of Turkey and Iran.

Distribution in Armenia. The species is met in northwestern, central and southern regions of the republic, mainly in mountain-steppe landscapes and high altitude meadows at an altitude of $1200-3000 \mathrm{~m}$ above sea level.

Habitats. In Armenia it inhabits very rocky, Mountain xerophytes steppes and Alpine meadows. It can also be met in mountainous light forests, between the slits of collapsed stones of the mountain slopes, locoweed and other xerophyte plants. They are rarely met in cultivated landscapes under the heaps of stones. They use nests of the rodents as hiding places, empty places under the stones, bottoms of various plants, cracks of rocks and ground etc.

Biological peculiarities. They are active from the midApril up to mid-October. They feed on lizards and invertebrates. The coupling takes place in April/May depending on the height of the habitat and the terms of coming out of hibernation. Live-bearing (viviparous) species .The birth of the babies starts from the end of July and lasts till the midSeptember. Pregnancy lasts 90-130 days. The babies are born from mid-August till the end of September.

Quantity and its change tendencies. The quantity is not large, in foothill biotopes especially stone accumulations where they gather 6-8 individuals can be met on 1 ha. On the whole the quantity is stable which is connected with the distribution of the viper in high altitude belts.

Main factors of endangering. Grazing of small cattle in the mountain steppe and meadow belts.

Conservation measures. It is conserved in the small parts of the mountain steppe regions of Khosrov Forest State Reserve. It is necessary to take under control isolated populations situated in the north of Armenia (foundation of sanctuaries) and to expand the boundaries of Khosrov Forest Reserve.

\section{Armenian or Radde's Viper, Vipera (Montivipera) Raddei Boettger, 1890} [1, 20, 27-29]

\section{Order SERPENTES}

Family Vipers and pit vipers, Viperidae

Status. Endemic species of the Armenian Plateau. It is registered in the in the Red Book of former USSR. The species is included in IUCN Red List (ver. 3.1) as Near Threatened. According to IUCN (International Union for Conservation of Nature and Natural Resources) Red List Criteria it is evaluated as Vulnerable - VU B1a+2b (ii, iii).

Distribution. Eastern Transcaucasia, Turkey, and neighboring regions of Iran. The area of distribution passes through the southern regions of Small Caucasus mountain chains within the borders of Transcaucasia.

Distribution in Armenia. Separated populations among which various obstacles are present, are situated in Hrazdan, Ararat, Vayots Dzor, Syuniq Marzes.

Habitats. It inhabits mountainous-xerophytic forests, juniper light forests, mountain steppes, rocky slopes covered with tree-bush light vegetation at an altitude of 1300$1800 \mathrm{~m}$ above sea level. Sometimes it climbs up to 2500 $2700 \mathrm{~m}$. At times it enters into cultivated fields where it stays on the heap of the stones.

Biological peculiarities. It is active from the beginning of April up to the end of October. Sexual activity begins from mid-October and continues till the end of June. Pregnancy lasts 150-160 days. The babies can be seen from the end of August till the second half of September. Reproduction cycle of the females of Vipera (Montivipera) raddei is mainly two years in the wild.

Quantity and its change tendencies. Sharp decrease in the quantity is observed in the latest years.

Main factors of endangering. Degradation of distinctive habitats caused by the plowing of mountain slopes, reconstruction works, by extermination of mountain forests, as well as grazing in the mountain steppes and meadow belts, illegal catch as well.

Conservation measures. The small part of the distribution area of the species is conserved in Shikahogh and 
Khosrov Forest State Reserves. Laboratory methods of conservation and reproduction of vipers are worked out and experimented. It is necessary to organize a number of sanctuaries in Abovyan (Kotayk Marz) and to define strong control over the illegal catch of the species.

\section{Concluding Remarks}

The present Red Data Book of the Republic of Armenia serves to help withstand the dangers faced now by biodiversity and to preserve the rare and endangered species. The Red Data Book has been maintained to contribute to census, conservation, recovery, development and application of focused and scientifically justified measures and related awareness-raising of population. Information about population decline, range shrinkage, deterioration of living conditions and direct threats to survival suffices to put species into the Red Data Book.

\section{References}

[1] [Aghasyan A. L. (1996). Fauna of snakes of Armenia and Nakhichevan region]. Candidate thesis. Yerevan, 38 p. [in Russian]

[2] Darevsky I. S. (1975). [Endangered and rare species of Amphibians and Reptiles of Trans Caucasus]. In: Fauna and its protection in Trans Caucasus' republics. Yerevan: NAS RA, pp. 64-67. [in Russian]

[3] [Tunijev B. S., Orlov N. L., Ananjeva N. B., Aghasyan A. L. (2009). Snakes of Caucasus. Taxonomic biodiversity, distribution, protection]. Sankt-Petersburg-Moscow, 303 p. [in Russian]

[4] Red Data Book of Armenia. (2010). Invertabrate and Vertebrate animals / eds. A. L. Aghasyan, M. Ju. Kalashyan. Yerevan: Ministry of Nature Protection, $268 \mathrm{p}$.

[5] Aghasyan A. L., Aghasyan L. A., Kaloyan G. A. (2009). Study of the present status of amphibian and reptile populations for updating the Red Data Book of Armenia and the IUCN Red List. In: Status and protection of globally threatened species in the Caucasus (eds. N. Zazanashvili and D. Mallon). Tbilisi, CEPF/WWF, pp. 125-131.

[6] IUCN Red List of Threatened Species. Ver. 2009.1. www.iucnredlist.org

[7] WWF monitoring reports. 2002-2010. World Wide Fund for Nature (WWF) Armenian branch. Yerevan.

[8] [Yeghiasaryan E. M. (2008). Fauna and ecology of Amphibians of Armenia]. Candidate thesis. Yerevan, 44 p. [in Russian]

[9] [Red Data Book of Armenia]. (1987). Animals. Yerevan: Ajastan, 123 p. [in Russian]

[10] [Tunijev B. S., Bakradze M. A., Beregovaja S. Ju. (1987). Distribution and ecology of Northern banded newt [Triturus vittatus (Jenyns, 1835)]. Proc. of Institute of Zoology NAS RA. V. 158, pp. 161-170. [in Russian]

[11] [Ananjeva N. B., Borkin L. J., Darevsky I. S., Orlov N. L.
(1998). Amphibians and Reptiles. Encyclopedy of Nature of Russia]. Moscow: ABF, 576 p. [in Russian]

[12] [Papanyan S. B. (1956). Data on distribution of Pelobates syriacus in East Trans Caucasus]. Proc. of NAS RA. Biological Sciences. V. 9, № 1. pp. 9-12. [in Russian]

[13] [Papanyan S. B. (1959). Ecology of Eastern spadefoot (Pelobates syriacus Boettger) in Armenia]. Proc. of NAS RA. Biological Sciences. V. 12, № 12. pp. 6-8. [in Russian]

[14] Serbinova I.A., Aghasyan A.L, Goncharov B.F., Uteshov V.K. (1988). Haltung, Vermehrung und Reintroduktion von Pelobates syriacus Boettger, 1889. Tangungsmaterial Haltung und Vermehrung von Amphibien in Labor und Terrarium, pp. 41-46.

[15] [Aghasyan A. L. (1986a). Breeding of the Mediterranean tortoise in captivity]. Proc. of the All-Union Conf. on Problems of zoo culture. P. II, Moscow, pp. 108-110. [in Russian]

[16] [Ananjeva N., Mjasnikova N., Aghasyan A. (2006). Analysis of distribution of Phrynocephalus persicus (Agamidae, Sauria) in Araks valley]. In: Contemporary Herpetology, V. 5/6, pp. 18-40. [in Russian]

[17] [Aghasyan A. L. (1985a). Contemporary state of rare species of Reptiles of Armenia and ways of their conservation]. Biological Journal of Armenia. V. 38, № 8, pp. 661-665. [in Russian]

[18] [Ananjeva N., Orlov N., Khalikov R., Darevsky I., Rjabov S., Barabanov A. (2004). Atlas of Reptiles of North Eurasia (taxonomic biodiversity, distribution and protection state)]. Sankt-Petersburg: Institute of Zoology, 232 p. [in Russian]

[19] [Darevsky I. S. (1967). Rock lizards of Caucasus]. Leningrad: Nauka, 214 p. [in Russian]

[20] [Aghasyan A. L. (1987). Snakes of Yerevan neighborhood and adjacent territories]. Herpetological studies in Caucasus. Proc. of Institute of Zoology NAS RA. V. 158, pp. 26-32. [in Russian]

[21] [Aghasyan A. L. (1986b). Rescue from disappearance]. Priroda Armenii. № 2, pp. 8-13. [in Russian]

[22] [Aghasyan A. L., Tuniyev B. S. (2001). The rarest snake in USSR]. Nature, № 5, pp. 42-43. [in Russian]

[23] [Aghasyan A. L. (1998). Ecology of the Darevsky's viper (Vipera darevskii Vedmederja, Orlov et Tuniyev, 1986) in highlands]. Proc. of the Republic Sci. Conf. on Zoology. Yerevan: NAS RA, pp. 6-7. [in Russian]

[24] [Aghasyan L. A., Aghasyan A. L. (2008). New data to distribution and protection of the Darevsky's viper (Vipera darevskii Vedmederja, Orlov et Tuniyev, 1986)]. In: Problems of Herpetology. Sankt-Petersburg, Institute of Zoology, pp. 7-10. [in Russian]

[25] Aghasyan L. A. (2005-2006). Development of conservation measures for the Darevsky's viper in the Caucasus. Annual report to BPCP, $39 \mathrm{p}$.

[26] Aghasyan L. A. (2007-2008). Conservation and further research of distribution of the critically endangered $\mathrm{Da}$ revsky's viper (Vipera darevskii) in Armenia. Annual report to BP-CLP, $51 \mathrm{p}$.

[27] [Aghasyan A. L. (1989). Ecology of the Armenian viper (Vipera raddei) in Abovyan neighborhood]. In: Problems of 
Herpetology, Kijev: Naukova dumka, pp. 5-6. [in Russian]

[28] Ettling J. (2004-2010). Using radio telemetry to study the movement patterns, home range size and habitat preferences of the Armenian viper (Montivipera raddei) in Armenia.
Annual reports.

[29] [Aghasyan A. L. (1985b). Reproduction of Armenian viper in terrarium]. In: Problems of Herpetology. Leningrad: Nauka, pp. 4-5. [in Russian]. 